\title{
Immunopathogenesis and Immunotherapy for Viral Hepatitis
}

\author{
Yukihiro Shimizu \\ Gastoenterology Unit, Takaoka City Hospital, Toyama, \\ Japan
}

\section{Introduction}

Neither hepatitis B virus (HBV) nor hepatitis C virus (HCV) is cytopathic, and hepatitis is caused by the host immune response against virus-related peptides expressed on hepatocytes in conjunction with human leukocyte antigens (HLA). In acute self-limiting hepatitis, a broad immune response occurs that is strong enough to eradicate the virus or suppress viral replication (Rehermann, 1996). However, there are many mechanisms that hamper the antiviral immune response leading to persistent infection. To develop an optimal strategy to stimulate antiviral immune response with therapeutic potential, extensive analyses of immune mechanisms for successful viral eradication and immunosuppressive mechanisms induced by viral infection during persistent infection are required. The first half of this chapter discusses these points, followed by a discussion of immunotherapeutic approaches in both animal models and humans in the second half.

\section{Immunological response in viral infection}

\subsection{Acute viral hepatitis}

Immunological analysis has been extensively performed in transgenic and chimpanzee models of acute HBV infection. In one model, transgenic mice, in which infectious HBV virions replicate in the liver with expression of all HBV-related antigens, were injected with HBsAg-specific cytotoxic T lymphocytes (CTLs) that had been induced in nontransgenic mice. The injected CTLs produced interferon (IFN)- $\gamma$ and tumor necrosis factor (TNF)- $\alpha$, which purged viral RNA and DNA without destroying infected hepatocytes (Guidotti et al., a 1996; Chisari, 1997; Guidotti et al., 2001). Importantly, this noncytolytic clearance of intracellular HBV is more efficient at controlling HBV replication than the killing of infected hepatocytes. In this sense, hepatitis is not only a harmful event but also represents an effective mechanism by which CTLs suppress HBV. It is important to note that in the HBV transgenic mouse model of acute hepatitis, administration of antibodies against the chemokines, IFN- $\gamma$-inducible protein (IP-10) and monokine induced by interferon- $\gamma$ (Mig) reduced the recruitment of mostly Ag-nonspecific mononuclear cells into the liver that had been induced by cytokines and chemokines produced by injected CTLs, leading to a reduction in the severity of hepatitis without affecting the antiviral activity of the CTLs (Kakimi et al., 2001). These observations have important therapeutic implications, because suppression of Ag-nonspecific mononuclear cell recruitment may suppress hepatitis while 
retaining the antiviral function of the CTLs. Noncytolytic viral eradication can account for recovery from acute $\mathrm{HBV}$ infection in that most $\mathrm{HBV}$ is cleared from hepatocytes with only a fraction of the hepatocytes being destroyed. This was confirmed in a chimpanzee infection model; HBV DNA level was markedly decreased in the liver and blood of acutely infected chimpanzees before peak serum alanine aminotransferase (ALT) concentrations were reached (Guidotti et al., 1999), suggesting that this noncytopathic T cell effector mechanism results in early viral inhibition or eradication, whereas a cytopathic $\mathrm{T}$ cell effector mechanism would be required to eliminate the remaining virus by destroying infected hepatocytes.

In humans, the HBV-specific T cell response during incubation phase of acute hepatitis $B$ has been analyzed extensively using HLA class I tetramer and cytokine staining (Webster et al., 2000). The data showed that maximal reduction in HBV DNA in the serum occurred before the peak of ALT elevation, again indicating that suppression of HBV replication occurs without hepatocyte injury. Moreover, infiltration of HBV-specific CD8 ${ }^{+} \mathrm{T}$ cells into the liver has been observed several weeks before the peak of liver injury, suggesting that $\mathrm{HBV}$-specific $\mathrm{T}$ cell infiltration occurs at an early stage of infection resulting in suppression of HBV replication. Thereafter, recruitment of mostly nonspecific cells induced by cytokines or chemokines produced by HBV-specific T cells contributes to significant liver damage.

The overall data from studies in mice, chimpanzees, and humans are essentially the same, and indicate that a sufficient $\mathrm{T}$ cell response to $\mathrm{HBV}$ at an early phase of infection is important for eradication of virus infection, and that an insufficient $\mathrm{T}$ cell response may lead to persistent viral infection.

The same is essentially true in acute $\mathrm{HCV}$ infection. Multispecific and vigorous CTL responses against HCV antigens are important for successful eradication of the virus. Moreover, a CD4+ $\mathrm{T}$ cell response at an early stage of acute infection and persistence of the response are apparent in acute infection (Semmo et al., 2007). In contrast to acute HBV infection, the majority of patients with acute $\mathrm{HCV}$ infection progress to persistent infection, and the mechanisms underlying failure to eradicate the virus have been analyzed. The failure of $\mathrm{CD}^{+} \mathrm{T}$ cell function is a key factor in $\mathrm{HCV}$ persistence and $\mathrm{CD} 4^{+} \mathrm{T}$ cells from persistent infection do not produce Th1 cytokines, such as IFN- $\gamma$ and IL-2, but produce IL-4 and IL-10, clearly distinct from those seen in patients with recovery (Tsai et al., 1997). Moreover, an early and strong Th1 response has been shown to play an important role in disease resolution. One possible mechanism explaining why the Th2 type $\mathrm{CD}^{+} \mathrm{T}$ cell response is dominant in patients with persistent infection is a defective function of dendritic cells, possibly due to lack of IL-12 production (Fowler et al., 2003).

\subsection{Antigen-specificity of $T$ cell response in viral hepatitis}

The antigen-specificity of the T cell response to HBV in acute hepatitis has been analyzed, and it is clear that acute viral hepatitis involves a vigorous CTL response to multiple epitopes in the viral nucleocapsid, envelope, and polymerase proteins, while these are not seen in patients with chronic hepatitis (Rehermann, 1996). Although multi-specificity of the CTL response is characteristic in acute hepatitis, there is known to be a hierarchy of epitopespecific $\mathrm{CD}^{+} \mathrm{T}$ cell responses determined by cytokine production after peptide stimulation. In acute hepatitis $\mathrm{B}, \mathrm{CD} 8^{+} \mathrm{T}$ cell response to HBc18-27 (HLA-A2 restricted epitope) is dominant followed by the response to polymerase epitope $(455-463)$, whereas envelope epitopes are always subdominant (Webster et al., 2001). The hierarchy is clearly distinct 
from that observed in chronic hepatitis, in which the $\mathrm{CD} 8^{+} \mathrm{T}$ cell response to envelope epitope $(183-191)$ is always dominant. Interestingly, chronic hepatitis patients with lower HBV DNA levels in the serum show greater responses to HBc18-27 than those with high HBV DNA. These findings imply that the T cell response to HBcAg is important for viral control, which is important for designing peptide vaccines for the treatment of chronic HBV infection.

In acute $\mathrm{HCV}$ infection, the CTL responses were directed against multiple viral epitopes, in particular within the structural (core) and nonstructural (NS) regions of the virus (NS3, NS4, and NS5), and the CTL frequencies were higher in patients with acute infection (Cucchiarini et al., 2000; Lechner et al., 2000) than in those who develop persistent infection. The hierarchy of HCV epitopes has not been analyzed extensively, but resolution of primary infection in the chimpanzee was shown to be associated with a dominant $\mathrm{CD}^{+} \mathrm{T}$ cell response against epitopes including NS3 (GYKVLVLNPSV), suggesting the existence of an HCV epitope hierarchy (Shoukry et al., 2004).

\subsection{Chronic hepatitis}

In contrast to acute hepatitis, the T cell response to HBV is weak and is narrowly focused in chronically infected patients (Chisari et al., 1995), suggesting that it may be a cause of persistent infection.

HBV-specific helper and cytotoxic T lymphocytes (CTLs) are barely detectable in peripheral blood of patients with chronic hepatitis B (Ferrari et al., 1990), possibly due to exhaustion by high viral load or tolerance to HBV. Maini et al. (2000) reported that the number of HBVspecific T cells, detected using tetramers was the same in livers with low HBV DNA/ALT as in those with high HBV DNA/ALT. Hence, HBV-specific T cells recognize HBV antigens and carry out immune surveillance in the liver. Thus, they have an important role in controlling HBV replication in the liver without causing hepatic necroinflammation in low DNA/ALT anti-HBe ${ }^{+} \mathrm{HBV}$ carriers. It remains unknown why HBV-specific $\mathrm{T}$ cells fail to effectively control HBV replication in the liver with chronic hepatitis. However, recent advances in immunology have given some insight into the mechanism as described below. In contrast to chronic HBV infection, CTL response against various HCV epitopes including core, envelope and NS regions can be detected in chronic HCV infection, especially in liverinfiltrating lymphocytes (Koziel et al, 1995). Although intrahepatic CTL response was shown associated with low viral load (Freeman et al, 2003), the CTL response is not enough to terminate $\mathrm{HCV}$ infection possibly due to the presence of immunosuppressive mechanisms similar to chronic HBV infection.

\section{Immunosuppressive mechanisms responsible for persistent hepatitis virus infection}

\subsection{Regulatory $T$ cells (Tregs)}

Tregs expressing the forkhead family transcription factor, Foxp3, are specialized cells that exert negative control on a variety of physiological and pathological immune responses, resulting in maintenance of immunological self-tolerance (Miyara et al., 2011). They show diverse phenotypes, occurring in both $\mathrm{CD}^{+}$and $\mathrm{CD}^{+} \mathrm{T}$ cell subsets, and express CD25 (IL-2 receptor $\alpha$ chain) and/or cytotoxic T-lymphocyte antigen 4 (CTLA-4) in addition to Foxp3. 
In HBV infection, HBeAg-positive patients with high HBV DNA levels in the serum showed elevated numbers of $\mathrm{CD} 4{ }^{+} \mathrm{CD} 25^{+}$Treg cells in the blood compared to patients with acute or chronic HCV infection (Xu et al., 2006). Significant accumulation of CD4 ${ }^{+} \mathrm{CD} 25^{+} \mathrm{FoxP}{ }^{+}$Treg cells in the liver was found in patients with chronic HBV infection. Moreover, patients with high viral load have a higher proportion of Tregs in the liver (Stoop et al., 2008), suggesting that intrahepatic Tregs suppress antiviral immune responses in the liver in chronic hepatitis $\mathrm{B}$ virus infection. In $\mathrm{HCV}$ infection, it has also been shown that a higher frequency of $\mathrm{CD} 4{ }^{+} \mathrm{CD} 25^{+}$regulatory $\mathrm{T}$ cells in the blood of chronically $\mathrm{HCV}$-infected patients versus recovered or healthy individuals (Cabrera et al., 2004; Boettler et al., 2005) and the presence of $\mathrm{CD}^{+}{ }^{+} \mathrm{FoxP}^{+}{ }^{+} \mathrm{T}$ cells in the liver of chronically HCV-infected patients (Sturm et al., 2010).

\subsection{Programmed Death-1 (PD-1)}

PD-1 is a surface receptor critical for the regulation of $\mathrm{T}$ cell function (Francisco et al., 2010; Fife et al., 2011). Binding to PD-1 by its ligands PD-L1 and PD-L2 results in the antigen-specific inhibition of $\mathrm{T}$ cell proliferation, cytokine production, and cytolytic function, leading to exhaustion of T cells. In the liver, PD-1 is expressed on lymphocytes; PD-L1 is expressed on lymphocytes, hepatocytes, and sinusoidal endothelial cells, and PD-L2 is expressed on Kupffer cells and DCs (Chen et al., 2010). HBeAg-positive patients with high HBV DNA levels in the serum showed increased PD-1 and CTLA-4 expression on HBV-specific CD8 ${ }^{+} \mathrm{T}$ cells (Peng et al., 2011). Moreover, PD-1 expression on CD4 ${ }^{+} \mathrm{T}$ cells is correlated positively with serum HBV DNA load in CHB patients (Nan et al., 2010). Intrahepatic HBV-specific CD8 ${ }^{+} \mathrm{T}$ cells express higher levels of PD-1, and upregulation of intrahepatic PD-1/PD-L1 is associated with liver inflammation and ALT elevation (Fisicaro et al., 2010). Although the mechanism underlying the upregulation of PD-1 on CD8 ${ }^{+} \mathrm{T}$ cells in the inflamed liver is unknown, signals from PD-1 inhibit HBVspecific $\mathrm{T}$ cells, resulting in insufficient antiviral responses leading to failure of viral control and persistent liver inflammation. Importantly, PD-1/PD-L1 blockade increased $\mathrm{CD}^{+} \mathrm{T}$ cell proliferation and enhanced IFN- $\gamma$ and IL-2 production by intrahepatic lymphocytes (Fisicaro et al., 2010). These findings suggest that inhibition of PD-1/PD-L1 may have therapeutic potential for the control of hepatitis B.

Similar to $\mathrm{T}$ cells in patients with chronic hepatitis $\mathrm{B}$, circulating and intrahepatic HCVspecific CD8+ T cells were found to express high levels of PD-1 (Golden-Mason et al., 2007), and PD-1 expression level in the liver is higher than that in peripheral blood. Increased expression of PD-1 is associated with CD8 $8^{+} \mathrm{T}$ cell dysfunction, and functional restoration is achieved by blocking the signal from PD-1 (Penna et al., 2007). Recently, HCV core protein was shown to induce PD-1 and PD-L1 on T cells from healthy donors (Yao et al., 2007), indicating that immunosuppressive ability of $\mathrm{HCV}$ core protein is mediated by the upregulation of inhibitory molecules on T cells. Increased PD-1 expression on HCV-specific CTLs was reported to be significantly associated with poor response to antiviral therapy (Golden-Mason et al., 2008), and PD-L1 expression on DCs is increased during IFN-a treatment (Urbani et al., 2008), suggesting that PD-1/PD-L1 is associated with the efficacy of antiviral treatment. PD-1 is also expressed on Tregs in the liver, and the signal from PD-1 ligation provides an overall inhibitory signal to Tregs. PD-1 blockade enhanced IL-2dependent proliferation of intrahepatic Tregs in response to HCV antigens and enhanced the inhibitory ability of Tregs ((Franceschini et al. 2009), suggesting that complex interactions determine the direction of antiviral immune response. 


\subsection{Interluekin-10 (IL-10)}

Interleukin (IL)-10 is an important cytokine with anti-inflammatory properties, and is produced by activated monocytes/macrophages and T cell subsets, including Treg and Th1 cells (Sabat et al., 2010). Immunosuppression by IL-10 is associated with functional exhaustion of memory $\mathrm{T}$ cells in chronic lymphocytic choriomeningitis virus (LCMV) infection, and blockade of IL-10 receptors could terminate chronic LCMV infection (Ejrnaes et al., 2006). In chronic HBV infection, $\mathrm{HBcAg}$ stimulates the production of IL-10, which negatively regulates $\mathrm{HBCAg}$-specific Th17 cell responses in CHB patients (Li et al., 2010).

In HCV infection, peripheral blood mononuclear cells produce IL-17, IFN- $\gamma$, IL-10, and TGF$\beta$ in response to NS4 protein of HCV, and neutralization of TGF- $\beta$ or IL-10 significantly enhances NS4-specific IL-17 and IFN- $\gamma$ production by T cells from HCV-infected patients (Rowan et al., 2008). Moreover, lipopolysaccharide and HCV core protein trigger IL-10 and TNF- $\alpha$ production from monocytes, but at much lower levels from monocytes in patients with self-limiting HCV infection (Martin-Blondel et al., 2008). These data indicate that HCV proteins induce IL-10 from monocytes in patients with chronic HCV infection, leading to suppression of antiviral immune response.

\subsection{T-cell immunoglobulin and mucin domain-containing molecule-3 (Tim-3)}

It has been reported that not all exhausted $\mathrm{T}$ cells show upregulation of PD-1 and downregulation of CD127 (IL-7 receptor), and blockade of the PD-1/PD-L1 signaling pathway does not always restore proliferation and cytokine production (Golden-Mason et al., 2009). Recently, another inhibitory molecule, Tim-3, has been reported. A high frequency of Tim3-expressing $\mathrm{CD}^{+}$and $\mathrm{CD}^{+} \mathrm{T}$ cells are found in chronic HBV infection, and the frequency of Tim-3+ $\mathrm{T}$ cells was positively correlated with the severity of liver inflammation, and negatively correlated with plasma IFN- $\gamma$ levels (Ju et al., 2009). Tim-3 was also highly expressed on $\mathrm{CD}^{+}$and $\mathrm{CD} 8{ }^{+} \mathrm{T}$ cells in $\mathrm{HCV}$ infection, with the highest levels seen on HCVspecific CTLs. Tim-3 expression is associated with reduced Th1/Tc1 cytokine production, and blocking the Tim-3 - Tim-3 ligand interaction could enhance CD4 ${ }^{+}$and $\mathrm{CD}^{+} \mathrm{T}$ cell proliferation in response to HCV-specific antigens (Golden-Mason et al., 2009).

\subsection{Dysfunction of DCs}

DCs are specialized antigen-presenting cells that orchestrate immune responses. They stimulate innate and acquired immune responses, but also act as tolerogenic cells for immune responses in a variety of situations. In viral hepatitis, dysfunction of DCs from peripheral blood has been reported. In patients with chronic hepatitis B, maturation of DCs from peripheral blood of patients after incubation with cytokines is lower than that of normal subjects with lower expression of HLA-DR and costimulatory molecules in the former population (Wang et al., 2001), leading to low allostimulatory function of DCs from $\mathrm{CHB}$ patients. The mechanism of impairment of DC function in patients with chronic hepatitis $B$ is unclear, but both $\mathrm{HBV}$ particles and purified HBsAg may have immunomodulatory capacity and may directly contribute to the dysfunction of myeloid DCs (Op den Brouw et al., 2009). Importantly, impaired function of monocyte-derived DCs from patients with $\mathrm{CHB}$ could be reversed by inhibiting viral replication with nucleoside analogs such as lamivudine (Beckebaum et al., 2003). Type 2 precursor plasmacytoid dendritic cells (pDCs), which are the most important cells in antiviral innate immunity, were also reported to have quantitative and qualitative impairment in patients with chronic HBV 
infection (Duan et al., 2004). Recently, HBV itself was shown to inhibit the functions of pDCs (Woltman et al., 2011). These data indicate that DCs in patients with chronic hepatitis B have impaired function leading to insufficient $\mathrm{T}$ cell response to $\mathrm{HBV}$, which could be the mechanism responsible for persistent viral infection.

In chronic hepatitis C, DCs from patients also show impaired immunostimulatory function, which could be induced by HCV (Eksioglu et al., 2010) or NS4 protein (Takaki et al., 2010). Monocyte-derived DCs from $\mathrm{HCV}$ patients were shown to induce proliferation of $\mathrm{CD}^{+}{ }^{+} \mathrm{CD} 25^{+} \mathrm{FoxP}^{+}$regulatory $\mathrm{T}$ cells, which limit proliferation of $\mathrm{HCV}$-specific $\mathrm{T}$ lymphocytes (Dolganiuc et al., 2008). DCs in HCV patients thus inhibit T cell responses via a variety of mechanisms.

\section{Immunotherapy for viral hepatitis}

Therapeutic strategies for terminating viral infection should be evaluated based on the mechanisms responsible for insufficient antiviral immunological mechanisms leading to persistent viral infection. Most immunotherapeutic approaches for viral hepatitis have been directed against hepatitis $B$. This is likely due to the availability of good animal models of persistent $\mathrm{HBV}$ infection, ready availability of $\mathrm{HB}$ vaccine and accumulation of basic immunological analyses. Previous animal studies and human trials are listed in Tables 1 and 2 , respectively.

\section{Peptide vaccination}

Wang et al. 2010; A synthesized fusion peptide, consisting of HBcAg18-27 and HIV Tat4957 adjuvanted with $\mathrm{CpG}$ ODN increased $\mathrm{CD}^{+}, \mathrm{CD}^{+}$and $\mathrm{CD}^{+}$cells and the production of IFN- $\gamma$ and IL-2. Vaccination with the peptide reduced serum HBV DNA levels and decreased the expression levels of HBsAg and HBcAg in the livers of transgenic mice.

\section{Protein vaccination}

Akbar et al, 1997; HBV transgenic mice were treated with vaccine on the base of surface antigen in complete Freund's adjuvant once a month for 12 months. Most of the mice showed reduction of HBV DNA level and disappearance of HBeAg and HBsAg.

Menne et al, 2007; A combination of conventional vaccine on the base of the WHV large surface protein contained HBsAg with pre-S and clevudine significantly restored the Tcell response to Pre-S and $S$ region in chronic WHV infection.

Miller at al, 2008; One hour post-infection with DHBV, DNA vaccine expressing DHBc and Pre-S/S and entecavir were given simultaneously and continued for 14 days. Ducks boosted with fowl poxvirus vectors expressing DHBc and Pre-S/S showed clearance of DHBV infection at a rate of $100 \%$.

\section{DNA immunization}

Thermet et al, 2008; DNA vaccine encoding the DHBV large envelope and/or core protein was given 6 times with or without lamivudine in a DHBV model. Reduction of viremia and liver DHBV cccDNA was observed in 33\% of ducks receiving DNA vaccine mono- or combination therapy. Seroconversion to anti-pre $S$ was observed in $67 \%$ of ducks showing cccDNA clearance.

Encke et al, 2006; The combination of DNA vaccination encoding HCV core and mouse IL-2 breaks tolerance and activates previously tolerant $\mathrm{T}$ cells in an HCV transgenic mouse model. 


\section{DC immunization}

Shimizu et al, 1998; Activated bone marrow-derived DCs were shown to break CTL tolerance to HBsAg in HBV transgenic mice.

Kimura et al, 2002; A single injection of an anti-CD40 agonistic monoclonal antibody into HBV transgenic mice induced noncytopathic inhibition of HBV replication, which was mediated by antiviral cytokines (IL-12 and TNF- $\alpha$ ) produced by activated intrahepatic antigen-presenting cells.

Jiang et al, 2008; HBV transgenic mice were injected with HBV-specific peptide-pulsed DCs, and significant reductions in the serum HBsAg and HBV DNA concentrations were observed.

Díaz-Valdés et al, 2011; DCs, treated with peptide inhibitors of IL-10, induced strong anti$\mathrm{HCV}$ T cell responses in HCV transgenic mice.

Cytokines and adjuvants

Cavanaugh et al, 1997; Recombinant IL-12 markedly inhibits HBV replication in the liver of HBV transgenic mice through its ability to induce IFN- $\gamma$.

Kakimi et al, 2000; A single injection of $\alpha$-galactosylceramide that can activate Valpha14 ${ }^{+} \mathrm{NK} 1.1^{+} \mathrm{T}$ cells (NKT cells) abolished HBV replication in HBV transgenic mice.

Kimura et al, 2002; Injection of IL-18 into HBV transgenic mice inhibited HBV replication noncytopathically, which was mediated by activation of resident intrahepatic NK cells and NKT cells.

\section{Gene therapy}

Hong et al, 2011; Lentivectors expressing HBsAg and IgFc fusion Ag could effectively break immune tolerance and induced seroconversion to anti-HBs in HBsAg transgenic mice.

CpG ODN; CpG oligodeoxynucleotide, WHV; woodchuck hepatitis virus, DHBV; duck hepatitis B virus, cccDNA; covalently closed circular DNA, NKT; natural killer T

Table 1. Immunotherapeutic approaches for animal models of HBV and HCV infection.

\section{Peptide vaccination}

Heathcote et al, 1999; A vaccine with HBc18-27 peptide comprised of a T-helper cell epitope and two palmitic acid residues was administered to chronic hepatitis B (CHB) patients. Low levels of CTL activity were induced, but no significant changes in liver biochemistry or viral serology were observed.

Klade et al, 2008; A vaccine containing 7 relevant HCV T cell epitopes and the Th1 adjuvant poly-L-arginine, induced HCV-specific Th1/Tc1 responses in a subset of HCV patients not responding to or relapsing from standard therapy. However, only a minimal decrease in $\mathrm{HCV}$ viremia was induced by the vaccination.

Yutani et al, 2009; Vaccination with a peptide derived from HCV core protein induced both cellular and humoral responses in nearly all HCV patients with different HLA class I-A alleles, and reduced serum ALT and $\alpha$-fetoprotein levels in $29 \%$ and $50 \%$ of patients, respectively.

\section{Protein vaccination}

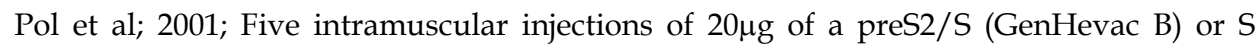


(Recombivax) vaccine in $\mathrm{CHB}$ patients showed $\mathrm{HBe} /$ anti-HBe seroconversion in $13 \%$ and HBV DNA negativity in $16 \%$ of the treated patients.

Dahmen et al, 2002; Intradermal commercially available HBV vaccine and laimvudine in combination with IL-2 induced a significant antiviral response, leading to HBV DNA loss in the serum in two of five patients with chronic hepatitis B.

Klein et al, 2003; Oral administration of HBV envelope proteins (HBsAg+preS1+preS2) to $\mathrm{CHB}$ patients three times a week for 20 to 30 weeks induced histological improvement in $30 \%$ of the patients, HBeAg negativity in $26.3 \%$ and HBsAg-specific T cell proliferation in $78 \%$.

Helvaci et al, 2003; Children with CHB were treated with IFN- $\alpha-2 b$ monotherapy (9 months) or IFN- $\alpha-2 b$ plus HBV pre-S2/S vaccine $(0,4,24$ weeks). The patients who received the combination therapy showed a greater reduction in HBV DNA than those who received IFN- $\alpha-2 b$ monotherapy.

Vandepapelière et al, 2007; In HBeAg-positive CHB patients, the combination with lamivudune and vaccine on the base of surface antigen with adjuvant did not improve the HBe seroconversion rate in comparison with lamivudine therapy alone.

Senturk et al, 2009; CHB patients who were treated with lamivudine and vaccine on the base of surface antigen showed sustained negativity of HBV DNA in $1 / 4$ of the treated patients.

Al-Mahtab et al, 2010; CHB patients were treated with lamivudine and vaccine on the base of surface antigen (5 times) for 12 months. HBV DNA became undetectable in $64 \%$ of the patients, and was decreased in the remaining patients at the end of the combination therapy. No patients showed ALT elevation.

\section{DNA immunization.}

Mancini-Bourgine et al, 2004; DNA vaccine encoding HBV envelope protein induced an increase in HBV-specific IFN- $\gamma$-secreting $\mathrm{T}$ cells in patients with $\mathrm{CHB}$, who had been nonresponders to conventional therapies, and HBV DNA levels were transiently decreased in $50 \%$ of vaccinated patients.

Mancini-Bourgine et al, 2006; DNA vaccine encoding PreS and S was administered to $\mathrm{HBeAg}^{+} \mathrm{CHB}$ patients with lamivudine breakthrough, and the patients developed IFN- $\gamma-$ producing $\mathrm{T}$ cells specific for preS or $\mathrm{S}$ antigen. Two of 10 patients showed seroconversion to anti-HBe.

Alvarez-Lajonchere et al; 2009; A new vaccine, CIGB0230, consisting of a mixture of plasmid expressing HCV structural antigens and HCV recombinant core protein, Co.120 was intramuscularly administered 6 times within 20 weeks in patients with chronic HCV infection. The vaccination induced specific $\mathrm{T}$ cell proliferation and IFN- $\gamma$ production in $73 \%$. More than $40 \%$ of vaccinees showed improvement of liver histology, despite persistent detection of HCV RNA.

\section{DC immunization}

Chen et al, 2005; Peripheral blood-derived DCs, activated with GM-CSF and IL-4, were pulsed with HBsAg, and were administered subcutaneously twice in $\mathrm{CHB}$ patients. Both patients with normal and elevated ALT responded equally to DC vaccine and $53 \%$ of the patients showed induction of HBeAg negativity. 
Luo et al, 2010; Activated DCs were generated from CD14 ${ }^{+}$cells of PBL with GM-CSF and IL-4, and two peptides, HBcAg18-27 and PreS244-53, were loaded. Aliquots of 5x106 to $3 \times 10^{7}$ DCs were infused intravenously, and reinfusion was performed once or twice a month for 3 months. Undetectable HBV DNA was achieved in $46.3 \%$ and $3.13 \%$ of $\mathrm{HBeAg}-$ and $\mathrm{HBeAg}^{+}$patients, respectively. ALT normalization was observed in $69 \%$ of $\mathrm{HBeAg}$ - patients and in $30.5 \%$ of $\mathrm{HBeAg}^{+}$patients.

Gowans et al, 2010; Monocyte-derived DCs loaded with lipopeptides consisting of HCVspecific HLA-A2.1-restricted CTL epitopes, can induce $\mathrm{HCV}$-specific $\mathrm{CD}^{+} \mathrm{T}$ cell responses with IFN- $\gamma$ production in PBL in $\mathrm{HCV}$ patients in whom conventional IFNbased therapy has failed. However, ALT levels were not elevated and viral load was not decreased.

\section{Cytokines}

Martin et al, 1993; Granulocyte macrophage-colony stimulating factor (GM-CSF) was safe and tolerable up to $1.0 \mu \mathrm{g} / \mathrm{kg}$ body $\mathrm{wt}$, and induced HBV DNA negativity in $4 / 8$ patients with chronic HBV infection.

Wang et al, 2002; Combination therapy with GM-CSF $(50 \mu \mathrm{g})$ and vaccine on the base of surface antigen $(10 \mu \mathrm{g})$ (four intramuscular injections) significantly reduced serum HBV DNA in HBV carrier children.

Zeuzem et al, 2001; HBV DNA clearance was observed in $25 \%$ of $\mathrm{CHB}$ patients treated with a high dose of IL-12 $(0.5 \mu \mathrm{g} / \mathrm{kg})$, and a reduction of $>50 \%$ in HCV RNA level was observed in $53 \%$ of CHC patients treated with the same dose of IL-12.

Rigopoulou et al, 2005; The addition of IL-12 to lamivudine therapy stimulated $\mathrm{T}$ cell response to HBV with IFN- $\gamma$ production. However, IL-12 was unable to suppress reelevation of HBV DNA after cessation of lamivudine.

Szkaradkiewicz et al, 2005; Combination of IL-12 and IL-18 stimulated IFN- $\gamma$ production by $\mathrm{CD}^{+} \mathrm{T}$ cells isolated from peripheral blood of children with chronic hepatitis $\mathrm{B}$ in response to $\mathrm{HBCAg}$, and the effect was greater than those observed with either cytokine alone.

Woltman et al, 2009; $\alpha$-galactosylceramide was administered to patients with chronic HBV infection. It was poorly tolerated and showed no clear suppressive effect on serum HBV DNA or ALT levels.

\section{Thymosin- $\alpha 1$ (Talpha1)}

Arase et al, 2003; The combination of Talpha1 and IFN- $\alpha$ for 24 weeks showed no statistically significant differences as compared with IFN- $\alpha$ monotherapy with respect to $\mathrm{HBeAg}$ seroconversion, changes in histology, normalization of ALT or loss of HBV DNA.

Iino et al, 2005; CHB patients were treated with Talpha1 for 24 weeks. At 12 months after cessation of therapy, $36.4 \%$ of patients treated with $1.6 \mathrm{mg}$ of Talpha1 achieved ALT normalization, $15 \%$ achieved HBV DNA clearance by transcription-mediated amplification, and $22.8 \%$ achieved clearance of HBeAg.

You et al, 2006; Efficacy of Talpha1 treatment was compared with IFN- $\alpha$, and Talpha1 treatment was more effective in achieving ALT normalization and HBV DNA negativity at the end of the follow-up period than IFN- $\alpha$. 
Lee et al, 2008; The combination of Talpha1 and lamivudine did not show any additional antiviral effect compared with lamivudine monotherapy as determined by $\mathrm{HBe}$ seroconversion and the emergence of viral breakthrough.

Zhang et al, 2009; A meta analysis demonstrated that combination therapy with lamivudine and Talpha1 yielded significantly higher rates of ALT normalization, virological response, and $\mathrm{HBeAg}$ seroconversion than lamivudine monotherapy.

Poo et al, 2008; Patients with chronic HCV infection who had been nonresponders to prior IFN- $\alpha$ and ribavirin were treated with Talpha1, PEG-IFN $\alpha-2 a$, and ribavirin for 48 weeks. Twenty-four percent of the treated patients with genotype 1 achieved a sustained virological response.

GM-CSF; granulocyte macrophage-colony stimulating factor

Table 2. Immunotherapeutic trials for chronic HBV and HCV infection in humans

\section{Immunotherapeutic approaches for viral hepatitis (Table 1 and 2)}

Immunotherapeutic strategies for viral hepatitis include suppression of viral replication, induction of immune response to hepatitis virus, activation of nonspecific cells, and administration of cytokines with antiviral activity.

\subsection{Suppression of viral replication}

High viral load has been shown to suppress $\mathrm{CD} 4^{+}$and $\mathrm{CD} 8^{+} \mathrm{T}$ cells in addition to induction of Tregs, which could be reversed by antiviral therapy (Boni et al., 2001). Therefore, immunotherapy followed by restoration of virus-specific $\mathrm{T}$ cell response with antiviral therapy could be more efficient, especially in CHB.

\subsection{Induction of immune response to hepatitis virus}

\subsubsection{Peptide immunization}

A peptide vaccine containing highly immunogenic HBc18-27 has been developed and administered to CHB patients (Heathcote et al., 1999), but the results were disappointing because there was no induction of a significant antiviral $\mathrm{T}$ cell response. There have also been no reports of efficient peptide vaccination in $\mathrm{HCV}$ infection.

\subsubsection{Protein immunization}

In a model of $\mathrm{HBV}$ in transgenic mice, vaccine on the base of surface antigen in complete Freund's adjuvant once a month for 12 months induced reduction in HBV DNA, and the disappearance of HBeAg and HBsAg in most mice treated. Moreover, it is important to note that some mice developed anti-HBs in the sera (Akbar et al., 1997). However, several human trials with vaccine on the base of surface antigen showed limited efficacy if used as monotherapy.

Recently, HB vaccine containing not only S protein but also preS has been used with increased immunogenicity (Pol et al., 2001, Klein et al., 2003), or has been combined with lamivudine or IFN- $\alpha$ (Helvaci et al., 2003) leading to potential improvement of clinical efficacy. However, analysis on the T cell epitope hierarchy indicated that the most important epitope for viral control is HBc18-27, and not the HBsAg epitope in HLA-A2 patients 
(Webster et al., 2001), suggesting the necessity of reconsidering antigen selection for vaccination that could lead to better viral control.

\subsubsection{DNA immunization}

Injection of plasmid DNA has been shown to strongly elicit both cellular and humoral immune responses, and is now known to be safe and well-tolerated both in mice and humans. In a model of duck hepatitis B virus infection, DNA vaccine encoding HBV large envelope and/or core protein was shown to induce reduction in not only viremia but also cccDNA in the liver in one third of ducks receiving DNA monotherapy or combination treatment along with lamivudine (Thermet et al., 2008). This finding is encouraging because clearance of cccDNA from the liver is the goal of treatment for HBV infection, but is difficult to achieve using IFN- $\alpha$ or nucleoside analogs. Clinical trials have also been performed in both HBV and HCV infection with some encouraging results (Table 2), which remain to be confirmed by future randomized large-scale trials.

\subsubsection{DC immunization}

DCs are specialized antigen-presenting cells that can induce strong immune responses in $\mathrm{T}$ and $\mathrm{B}$ cell. We have previously shown that activated bone marrow-derived DCs can break CTL tolerance to HBsAg in HBV transgenic mice (Shimizu et al., 1998). Thereafter, several immunotherapies with activated DCs have been applied in both animals and humans (Table 1 and 2). In a recent study performed in HBV transgenic mice, peptide-pulsed DCs were shown to significantly reduce the concentrations of serum HBsAg and HBV DNA (Jiang et al., 2003), indicating therapeutic potential in chronic HBV infection. Recently, DCs treated with peptide inhibitors of IL-10 were shown to induce strong anti-HCV T cell response in HCV transgenic mice (Díaz-Valdés et al., 2011), suggesting a strategy to augment the immunogenic function of DCs. Moreover, when intrahepatic antigen-presenting cells, including DCs, were activated by injection of an anti-CD40 agonistic antibody, HBV replication was inhibited by a noncytopathic mechanism possibly through production of antiviral cytokines such as TNF- $\alpha$ and IL-12 (Kimura et al., 2002a). Although no CTL response against $\mathrm{HBV}$ antigens was reported in this study, the in vivo activation of DCs could be an alternative way for inducing antiviral immune responses including possible activation of CTLs against HBV. In humans, injection of activated DCs loaded with HBV peptide or protein achieved a reduction in HBV DNA level in some patients (Chen et al., 2005, Luo et al., 2010). HBeAg negativity was achieved in more than half of the treated patients in one study (Chen et al., 2005). Although preparation of activated and mature DCs incurs financial costs and requires experienced researchers, immunotherapy with DCs is a promising method.

\subsubsection{Natural Killer T (NKT) cells}

A single injection of $\alpha$-galactosylceramide abolished HBV replication by activating NKT cells in the liver in HBV transgenic mice (Kakimi et al., 2000). However, $\alpha$ galactosylceramide was poorly tolerated in humans and showed no clear antiviral effect (Woltman et al., 2009), possibly due to smaller numbers of NKT cells in the human liver than in the mouse liver. 


\subsubsection{Cytokines and Thymosin- $\alpha 1$ (Talpha1)}

Cytokines such as IL-12 (Cavanaugh et al., 1997) and IL-18 (Kimura et al., 2000b) were shown to inhibit HBV replication noncytopathically in HBV transgenic mice. In humans, GM-CSF (Martin et al., 1993, Wang et al., 2002) and IL-12 (Carreño et al., Zeuzem et al., 2001, Rigopoulou et al., 2005) have been used for treatment with some antiviral effects. They have been used as monotherapy or in combination with $\mathrm{HB}$ vaccine or lamivudine.

Talpha1, a synthetic 28-amino acid peptide, is able to enhance the Thl immune response and also exerts a direct antiviral mechanism of action. It has been used for the treatment of chronic HBV (Arase et al, 2003, Iino et al., 2005, You et al., 2006, Lee et al., 2008) and HCV (Poo et al., 2008) infection in humans, and showed antiviral effect with some efficacy. Although antiviral effect by the addition of Talpha1 to lamivudine or IFN- $\alpha$ therapy was controversial, a meta analysis demonstrated that the combination therapy with lamivudine and Talpha1 showed significantly higher rates of ALT normalization, virological response, and HBeAg seroconversion as compared with lamivudine monotherapy (Zhang et al., 2009). It is of note that $\mathrm{HBeAg}$ seroconversion rate was $45 \%$ in the combination group, which was significantly higher than that with lamivudine monotherapy (15\%).

\section{DCs}

Akbar et al, 2010; DCs from peripheral blood and pulsed with $\mathrm{HBsAg} / \mathrm{HBcAg}$ could induce HBsAg- and $\mathrm{HBcAg}$-specific $\mathrm{T}$ cell proliferation in $\mathrm{CHB}$ patients.

PD-1

Nakamoto et al, 2009; CTLA-4 is preferentially expressed in PD-1+ $\mathrm{T}$ cells from the liver with chronic HCV infection, and coexpression of CTLA-4 and PD-1 is associated with T cell dysfunction. Combined blockade of these molecules, but not blocking of either molecule, can reverse $\mathrm{CD}^{+} \mathrm{T}$ cell exhaustion.

Ha et al, 2008; Blocking PD-1, CTLA-4 and IL-10 combined with therapeutic vaccination could synergistically enhance functional CD8 ${ }^{+} \mathrm{T}$ cell response and improve viral control in chronically infected mice. Moreover, addition of stimulatory signals, such as IL-2, could further increase the efficacy of the therapy.

\section{CD244}

Raziorrouh et al, 2010; PD-1 and CD244 are highly coexpreesed on virus-specific CD8+ T cells in chronic HBV infection. Blocking signals through CD244 and its ligand CD48 could restore T cell dysfunction independent of the PD-1 pathway.

\section{Tim-3}

McMahan et al, 2010; Blockade of Tim-3 on human HCV-specific CTLs increased cytotoxicity against an HCVAg-expressing hepatocyte cell line that expresses HCV epitopes.

Golden-Mason et al, 2009; Tim-3 expression was increased on both $\mathrm{CD}^{+}$and $\mathrm{CD}^{+} \mathrm{T}$ cells in chronic hepatitis $\mathrm{C}$ infection, and PD-1/Tim-3 double positive $\mathrm{T}$ cells are accumulated in the liver with chronic hepatitis C. Blocking Tim-3/Tim-3 ligand induced $\mathrm{T}$ cell proliferation and IFN- $\gamma$ production in response to $\mathrm{HCV}$ antigens.

\section{Gene transfection}

Zhang et al, 2010; Human T cells transduced with HCV TCR specific for HCV NS3 1071-1081 (HLA A2-restricted epitope) recognize the peptide and produced IFN- $\gamma$, IL-2 and TNF- $\alpha$.

PD-1; programmed death-1, CTLA-4; cytotoxic T lymphocyte antigen-4, Tim-3; T-cell immunoglobulin and mucin domain-containing molecule-3

Table 3. Human basic research for improvement of immunotherapy for viral hepatitis. 
Moreover, there have been several basic attempts to improve the efficacy of immunotherapy (Table 3). Among these reports, augmentation or restoration of T cell response by blocking the inhibitory signals have been extensively analyzed in vitro. It has been demonstrated that exhausted T cells express not only PD-1, but also CTLA-4 (Nakamoto et al., 2009), CD244 (Raziorrouch et al., 2010) or Tim-3 (Golden-Mason et al., 2009), and blocking of these molecules in combination could be better than blocking any single molecule to achieve full activation of the exhausted T cells.

\section{Conclusion}

There have been several attempts to apply immunotherapy for the control of chronic HBV and HCV infection, and some of the data are promising. Viral suppression, stimulation of antiviral immune response with cytokines, DNA or DC immunization and suppression of the immunoinhibitory signals must be combined to achieve desirable antiviral effects. Further studies are required to explore the best protocols and their most efficient combinations to become a promising and practical treatment.

\section{References}

Akbar, SM.; Kajino, K. Tanimoto, K. Kurose, K. Masumoto, T. Michitaka, K et al. (1997). J. Hepatol, Vol.26, No.1, (January 1997), pp. 131-137.

Akbar, SM.; Yoshida, O. Chen, S. Cesar, AJ. Abe, M. Matsuura, B et al. (2010). Antivir Ther, Vol.15, No.6, (2010), pp. 887-895.

Al-Mahtab M, Rahman S, Akbar SM, Khan SI, Uddin H, Karim F, et al. (2010). Viral Immunol, Vol.23, No.3, (June 2010), 335-338.

Alvarez-Lajonchere, L.; Shoukry, NH. Grá, B. Amador-Cañizares, Y. Helle, F. Bédard, N et al. (2009). J Viral Hepat, Vol.16, No.3, (October 2008), pp. 156-167.

Arase, Y.; Tsubota, A. Suzuki, Y. Suzuki, F. Kobayashi, M. Someya, T et al. (2003). Intern Med, Vol.42, No.10, (October 2003), pp. 941-946.

Barth, H.; Klein, R. Berg, PA. Wiedenmann, B. Hopf, U. \& Berg, T. (2001). Hepatogastroenterology, Vol.48, No.38, (March-April 2001), pp. 553-555.

Beckebaum, S.; Cicinnati, VR. Zhang, X., Ferencik, S. Frilling, A. Grosse-Wilde, H. et al. (2003). Immunology, Vol.109, No.4, (August 2003), pp. 487-495.

Boettler, T.; Spangenberg, HC. Neumann-Haefelin, C. Panther, E. Urbani, S. Ferrari, C et al. (2005). J Virol, Vol.79, No.12, (Junuary 2005), pp. 7860-7867.

Boni, C.; Penna, A. Ogg, GS. Bertoletti, A. Pilli, M. Cavallo, C. et al. (2001). Hepatology, Vol.33, No.4, (April 2001), pp. 963-971.

Cabrera, R.; Tu, Z. Xu, Y. Firpi, RJ. Rosen, HR. Liu, C. et al. (2004). Hepatology, Vol.40, No.5, (November 2004), pp. 1062-1071.

Cavanaugh, VJ.; Guidotti, LG. \& Chisari, FV. (1977). J Virol, Vol.71, No.4, (April 1997), pp. 3236-3243.

Chen, M.; Li, YG. Zhang, DZ. Wang, ZY. Zeng, WQ. Shi, XF. et al. (2005). World J Gastroenterol, Vol.11, No.12, (March 2005), pp. 1806-1808.

Chen, J; Wang, XM. Wu, XJ. Wang, Y. Zhao, H. Shen, B. et al. (2011). Inflamm Res, Vol.60, No.1, (July 2010), pp. 47-53. 
Chisari, FV. \& Ferrari, C. (1995). Springer Semin Immunopathol, (1995), Vol.17, No.2-3, pp. 261281.

Chisari, FV. (1997). J Clin Invest, Vol.99, No.7, (April 1997), pp. 1472-1477.

Cucchiarini, M.; Kammer, AR. Grabscheid, B. Diepolder, HM. Gerlach, TJ. Grüner, N. et al. (2000). Cell Immunol, Vol.203, No.2, (August 2000), pp. 111-123.

Dahmen, A.; Herzog-Hauff, S. Böcher, WO. Galle, PR. \& Löhr HF. (2002). J Med Virol, Vol.66, No.4, (Apr 2002), pp. 452-460.

Díaz-Valdés, N.; Manterola, L. Belsúe, V. Riezu-Boj, JI. Larrea, E. Echeverria, I. et al. (2011). Hepatology, Vol.53, No.1, (January 2011), pp.23-31.

Dolganiuc, A.; Paek, E. Kodys, K. Thomas, J. \& Szabo, G. (2008). Gastroenterology, Vol.135, No.6. (December 2008), pp. 2119-2127.

Duan, XZ.; Wang, M. Li, HW. Zhuang, H. Xu, D. \& Wang, FS. (2004). J Clin Immunol, Vol.24, No.6, (November 2004), pp. 637-646.

Ejrnaes M, Filippi CM, Martinic MM, Ling EM, Togher LM, Crotty S, et al. (2006). J Exp Med, Vol.203, No.11, (October 2006), pp. 2461-2472.

Eksioglu, EA.; Bess, JR. Zhu H. Xu Y. Dong, HJ. Elyar, J. et al. (2010). J Viral Hepat, Vol.17, No.11, (November 2010), pp. 757-769.

Encke, J.; Geissler, M. Stremmel, W. \& Wands, JR. (2006). Hum Vaccin, Vol.2, No.2, (March 2006), pp. 78-83.

Ferrari, C.; Penna, A. Bertoletti, A. Valli, A. Antoni, AD. Giuberti, T. et al. (1990). J Immunol, Vol.45, No.10, (November 1990), pp. 3442-3449.

Fife, BT. \& Pauken, KE. (2011). Ann N Y Acad Sci, Vol.1217, (January 2011), pp. 45-59.

Fisicaro, P; Valdatta, C. Massari, M. Loggi, E. Biasini, E. Sacchelli, L. et al. (2010). Gastroenterology. Vol.138, No.2, (September 2009), pp. 682-693, 693.e1-4.

Fowler, NL.; Torresi, J. Jackson, DC. Brown, LE. \& Gowans, EJ. (2003). Immunol Cell Bio, Vol.81, No.1, (February 2003), pp. 63-66.

Franceschini, D.; Paroli, M. Francavilla, V. Videtta, M. Morrone, S. Labbadia, G. et al. (2009). J Clin Invest, Vol.119, No.3, (Feuruary 2009), pp. 551-564.

Francisco, LM. Sage, PT. \& Sharpe, AH. (2010). Immunol Rev, Vol.236, (July 2010), pp. 219242.

Freeman, AJ.; Pan, Y. Harvey, CE. Post, JJ. Law, MG. White, PA. et al. (2003). J Hepatol, Vol.38, No.3, (March 2003), pp. 349-356.

Golden-Mason, L.; Palmer, B, Klarquist, J, Mengshol, JA, Castelblanco, N, \& Rosen, HR. (2007). J Virol, Vol.81, Vol.17, (June 2007), pp. 9249-9258.

Golden-Mason, L.; Klarquist, J. Wahed, AS. \& Rosen, HR. (2008). J Immunol, Vol.180, No.6, (March 2008), pp. 3637-3641.

Golden-Mason, L.; Palmer, BE. Kassam, N. Townshend-Bulson, L. Livingston, S. McMahon, BJ. et al. (2009). J Virol, Vol.83, No.18, (July 2009), pp. 9122-9130.

Gowans, EJ.; Roberts, S. Jones, K. Dinatale, I. Latour, PA. Chua, B. et al. (2010). J Hepatol, Vol.53, No.4, (June 2010), pp. 599-607.

Guidotti, LG; Ishikawa, T. Hobbs, MV. Matzke, B. Schreiber, R. \& Chisari, FV. (1996). Immunity, Vol.4, No.1, (January 1996), pp. 25-36.

Guidotti, LG; Rochford, R. Chung, J. Shapiro, M. Purcell, R. \& Chisari, FV. (1999). Science, Vol.284, No.5415, (April 1999), pp. 825-829. 
Guidotti, LG. \& Chisari, FV. (2001).. Annu Rev Immunol, Vol.19, pp. 65-91.

Ha, SJ.; West, EE. Araki, K. Smith, KA. \& Ahmed, R. (2008). Immunol Rev, Vol.223, (June 2008), pp. 317-333.

Heathcote, J.; McHutchison, J. Lee, S. Tong, M. Benner, K. Minuk, G. et al. (1999). Hepatology, Vol.30, No.2, (August 1999), pp. 531-536.

Helvaci, M.; Kizilgunesler, A. Kasirga, E. Ozbal, E. Kuzu, M. \& Sozen, G. (2004). J Gastroenterol Hepatol, Vol.19, No.7, (July 2004), pp. 785-791.

Hong, Y.; Peng, Y. Mi, M. Munn, DH. Wang, GQ. \& He ,Y. (2011). Vaccine, (Mar 2011)

Iino, S.; Toyota, J. Kumada, H. Kiyosawa, K. Kakumu, S. Sata, M. et al. (2005). J Viral Hepat, Vol.12, No.3, (May 2005), pp. 300-306.

Jiang, WZ.; Fan, Y. Liu, X. Zhang, YL. Wen, JJ. Hao, WL. et al. (2008). Antiviral Res, Vol.77, No.1, (September 2007), pp. 50-55.

Ju, Y.; Hou, N. Zhang, XN., Zhao, D. Liu, Y. Wang, JJ. et al. (2009). Cell Mol Immunol, Vol.6, No.1, (February 2009), pp.35-43.

Kakimi, K.; Guidotti. LG, Koezuka. Y \& Chisari, FV. (2000). J Exp Med, Vol.192, No.7, (October 2000), pp. 921-930.

Kakimi, K; Lane, TE. Wieland, S. Asensio, VC. Campbell, IL. Chisari, FV. et al. (2001). J Exp Med, Vol.194, No.12, (December 2001), pp. 1755-1766.

Kimura, K.; Kakimi, K. Wieland, S. Guidotti, LG. \& Chisari, FV. (2002a). J Immunol, Vol.169, No.9, (November 2002), pp. 5188-5195.

Kimura, K.; Kakimi, K. Wieland, S. Guidotti, LG. Chisari FV. (2002b) J Virol, Vol.76, No.21, (November 2002), pp. 10702-10707.

Klade, CS.; Wedemeyer, H. Berg T. Hinrichsen, H. Cholewinska, G. Zeuzem, S. et al. (2008). Gastroenterology, Vol.134, No.5, (March 2008), pp. 1385-1395.

Klein A, Hemed N, Segol O, Thalenfeld B, Engelhardt D, Rabbani E, et al. (2003). Am J Gastroenterol, Vol.98, No.11, (November 2003), pp. 2505-2515.

Koziel, MJ.; Dudley, D. Afdhal, N. Grakoui, A. Rice, CM. Choo, QL. et al. (1995). J Clin Invest, Vol.96, No.5, (November 1995), pp. 2311-2321.

Lechner, F.; Wong, DK. Dunbar, PR. Chapman, R. Chung, RT. Dohrenwend, P. et al. (2000). J Exp Med. Vol.191, No9, (May 2000), pp. 1499-1512.

Lee, HW.; Lee, JI. Um, SH. Ahn, SH. Chang, HY. Park, YK. et al. (2008). J Gastroenterol Hepatol, Vol.23, No.5, (May 2008), pp. 729-735.

Li, J.; Wu, W. Peng, G. Chen, F. Bai, M. Zheng, M. et al. (2010). Immunol Cell Biol, Vol.88, No.8, (May 2010), pp. 834-841.

Luo, J.; Li J. Chen, RL. Nie, L. Huang, J. Liu, ZW. et al. (2010). Vaccine, Vol.28, No.13, (January 2010), pp. 2497-2504.

Maini, MK.; Boni, C. Lee, CK. Larrubia, JR. Reignat, S. Ogg, GS. et al. (2000). J Exp Med, Vol.191, No.8, (April 2000), pp. 1269-1280.

Mancini-Bourgine, M.; Fontaine, H. Scott-Algara, D. Pol, S. Bréchot, C. \& Michel, ML. (2004). Hepatology, Vol.40, No.4, (October 2004), pp. 874-882.

Mancini-Bourgine, M.; Fontaine, H., Bréchot, C. Pol, S. \& Michel, ML. (2006). Vaccine, Vol.24, No.21, (August 2005), pp. 4482-4489.

Martin, J.; Bosch, O. Moraleda, G. Bartolome, J. Quiroga, JA. \& Carreño, V. (1993). Hepatology, Vol.18, No.4, (October 1993), pp. 775-780. 
Martin-Blondel, G.; Gales, A. Bernad, J. Cuzin, L. Delobel, P. Barange, K. et al. (2009). J Viral Hepat, Vol.16, No.7, (March 2009), pp. 485-491.

McMahan, RH.; Golden-Mason, L. Nishimura, MI. McMahon, BJ. Kemper, M. Allen, TM. et al. (2010). J Clin Invest, Vol.120, No.12, (November 2010), pp. 4546-4557.

Menne, S.; Tennant, BC. Gerin, JL. \& Cote, PJ. J Virol, Vol.81, No.19, (July 2007), pp. 1061410624.

Miller, DS.; Boyle, D. Feng, F. Reaiche, GY. Kotlarski, I. Colonno, R. et al. (2008). Virology, Vol.373, No.2, (April 2008), pp. 329-341.

Miyara, M. \& Sakaguchi, S. (2011). Immunol Cell Biol, Vol.89, No.3, (February 2011), pp. 346351.

Nakamoto, N.; Cho, H. Shaked, A. Olthoff, K. Valiga, ME. Kaminski, M. et al. PLoS Pathog, Vol.5, No.2, (February 2009), e1000313.

Nan, XP.; Zhang, Y. Yu, HT. Li, Y. Sun, RL. Wang, JP. et al. (2010). Viral Immunol, Vol.23, No.1, (February 2010), pp. 63-70.

Op den Brouw, ML.; Binda, RS. van Roosmalen, MH. Protzer, U. Janssen, HL. van der Molen, RG. et al. (2009). Immunology, Vol.126, No.2, (June 2008), pp. 280-289.

Peng, G.; Luo, B. Li, J. Zhao, D. Wu, W. Chen, F. et al. (2011). J Clin Immunol, Vol.31, No.2, (April 2011), pp. 195-204.

Penna, A.; Pilli, M. Zerbini, A. Orlandini, A. Mezzadri, S. Sacchelli, L. et al. (2007). Hepatology, Vol.45, No.3, (Mar 2007), pp. 588-601.

Pol, S.; Nalpa,s B. Driss, F. Michel, ML. Tiollais, P. Denis, J. et al. (2001). J Hepatol, Vol.34, No.6, (June 2001), pp. 917-921.

Poo, JL.; Sánchez Avila, F. Kershenobich, D. García Samper, X. Torress-Ibarra, R. Góngora, J. et al. (2008). Ann Hepatol, Vol.7, No.4, (October-December 2008), pp.369-375.

Raziorrouh, B.; Schraut, W. Gerlach, T. Nowack, D. Grüner, NH. Ulsenheimer, A. et al. (2010). Hepatology, Vol.52, No.6, (Novemver 2010), pp. 1934-1947.

Rehermann, B. Baillieres Clin Gastroenterol. (1996).Vol.10, No. 3 (September 1996), pp. 483500.

Rigopoulou, EI.; Suri, D. Chokshi, S. Mullerova, I. Rice, S. Tedder, RS. et al. (2005). Hepatology, Vol.42, No.5, (November 2005), pp. 1028-1036.

Rowan, AG.; Fletcher, JM. Ryan, EJ. Moran, B. Hegarty, JE. O'Farrelly, C. et al. (2008). J Immunol, Vol.181, No.7, (October 2008), pp. 4485-4494.

Sabat, R.; Grütz, G. Warszawska, K. Kirsch, S. Witte, E. Wolk, K. et al. (2010). Cytokine Growth Factor Rev, Vol.21, No.5, (Novermber 2010), pp. 331-344.

Safadi, R.; Israeli, E. Papo, O. Shibolet, O. Melhem, A. Bloch, A. et al. (2003). Am J Gastroenterol, Vol.98, No.11, (November 2003), pp. 2505-2515.

Semmo, N. \& Klenerman, P. (2007). World J Gastroenterol. Vol.13, No.36, (September 2007), pp. 4831-4838.

Senturk, H.; Tabak, F. Ozaras, R. Erdem, L. Canbakan, B. Mert, A. et al. (2009). Dig Dis Sci, Vol.54, No.9, (November 2008), pp. 2026-2030.

Shimizu, Y.; Guidotti, LG., Fowler, P. \& Chisari, FV. (1998). J Immunol, Vol.161, No.9, (November 1998), pp. 4520-4529.

Shoukry, NH.; Sidney, J. Sette, A. \& Walker, CM. (2004). J Immunol, Vol.172, No.1, (January 2004), pp. 483-92. 
Stoop JN, Claassen MA, Woltman AM, Binda RS, Kuipers EJ, Janssen HL, et al. (2008). Clin Immunol. Vol.129, No.3, (December 2008), pp. 419-427.

Sturm, N.; Thélu, MA. Camous, X. Dimitrov, G. Ramzan, M. Dufeu-Duchesne, T. et al. (2010). J Hepatol, Vol.53, No.1, (April 2010), pp. 25-35.

Szkaradkiewicz, A.; Jopek, A. \& Wysocki, J. (2005). Antiviral Res, Vol.66, No.1, (April 2005), pp. 23-27.

Takaki, A.; Tatsukawa, M. Iwasaki, Y. Koike, K. Noguchi, Y. Shiraha, H. et al. (2009). J Viral Hepat, Vol.17, No.8, (October 2009), pp. 555-562.

Thermet, A.; Buronfosse, T. Werle-Lapostolle, B. Chevallier, M. Pradat, P. Trepo, C. (2008). J Gen Virol, Vol.89, Vol. Pt 5, (May 2008), pp. 1192-1201.

Tsai, SL.; Liaw, YF. Chen, MH. Huang, CY.\& Kuo, GC. (1997). Detection of type 2-like Thelper cells in hepatitis $C$ virus infection: implications for hepatitis $C$ virus chronicity. Hepatology, Vol.25, No.2, (February 1997), pp 449-458.

Urbani, S.; Amadei, B. Tola, D. Pedrazzi, G. Sacchelli, L. Cavallo, MC. et al. (2008). J Hepatol, Vol.48, No.4, (January 2008), pp. 548-558.

Vandepapelière, P.; Lau, GK. Leroux-Roels, G. Horsmans, Y. Gane, E. Tawandee, T. et al. (2007). Vaccine, Vol.25, No.51, (October 2007), pp. 8585-8597.

Wang, FS.; Xing, LH. Liu, MX. Zhu, CL. Liu, HG. Wang, HF. et al. (2001). World J Gastroenterol, Vol.7, No.4, (August 2001), pp537-541.

Wang, J.; Zhu, Q., Zhang, T. \& Yu, H. (2002). Chin Med J, Vol.115, No.12, (December 2002), pp. 1824-1828.

Wang, S.; Han, Q. Zhang, N. Chen, J., Liu, Z. Zhang, G. et al. (2010). Immunol Lett, Vol.127, No.2, (October 2009), pp. 143-149.

Webster, GJ.; Reignat, S., Maini, MK. Whalley, SA. Ogg, GS. King, A. et al. (2000). Hepatology, Vol.32, No.5, (November 2000), pp. 1117-1124.

Webster, GJ. \& Bertoletti, A. (2001). Mol Immunol, Vol.38, No.6, (December 2001), pp. 467473.

Woltman, AM.; Ter Borg, MJ. Binda, RS. Sprengers, D. von Blomberg, BM. Scheper, RJ. et al. (2009). Antivir Ther, Vol.14, No.6, (2009), pp. 809-818.

Xing, Y.; Huang, Z. Lin, Y. Yang, Z. Yao, X. Guo, S. et al. (2008). Vaccine, Vol.26, No.40, (April 2008), pp. 5145-5152.

Xu D, Fu J, Jin L, Zhang H, Zhou C, Zou Z, et al. (2006). J Immunol, Vol.177, No.1, (July 2006), pp. 739-747.

Yao, ZQ.; King, E., Prayther, D. Yin, D. \& Moorman, J. (2007). Viral Immunol, Vol.20. No.2, (Summer 2007), pp. 276-287.

You, J.; Zhuang, L. Cheng, HY. Yan, SM. Yu, L. Huang, JH.et al. (2006). World J Gastroenterol, Vol.12, No.41, (November 2006), pp. 6715-6721.

Yutani, S.; Komatsu, N. Shichijo, S. Yoshida, K. Takedatsu, H. Itou, M. et al. (2009). Cancer Sci, Vol.100, No.10, (June 2009), pp. 1935-1942.

Zeuzem, S. \& Carreño, V. (2001). Antiviral Res, Vol.52, No.2, (November 2001), pp. 181188.

Zhang, Y.; Liu, Y. Moxley, KM. Golden-Mason, L. Hughes, MG. \& Liu, T. (2010). PLoS Pathog, Vol.6, No.7, (July 2010), e1001018. 
Zhang, YY.; Chen, EQ. Yang, J. Duan, YR. \& Tang, H. (2009). Virol J, Vol.25, No.6, (May 2009), pp.63. 


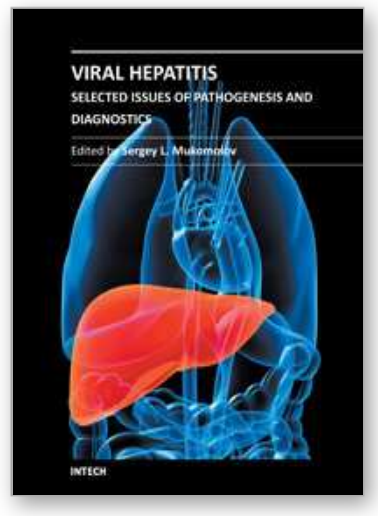

\author{
Viral Hepatitis - Selected Issues of Pathogenesis and Diagnostics \\ Edited by Dr. Sergey Mukomolov
}

ISBN 978-953-307-760-4

Hard cover, 152 pages

Publisher InTech

Published online 07, November, 2011

Published in print edition November, 2011

There are a lot of important issues related to viral hepatitis studies: molecular biology of viruses, laboratory diagnostics, epidemiology, treatment etc. However, there is a number of special textbooks and monographs on the subject. Considering this fact and rather fast progress in our understanding of the problem this book focuses on the important sections of the problem immune pathogenesis of parenterally transmitted viral hepatitis and some aspects of hepatitis diagnostics. Seven chapters were prepared by several groups of researchers to share information and results of studies with specialists working in the field and persons who are interested to learn about the viral hepatitis issue. The Nobel Prize Committee (the field of physiology and medicine, 2011) awarded Bruce A. Beutler and Jules A. Hoffmann for their discoveries concerning the activation of innate immunity whilst Ralph M. Steinman was awarded for his discovery of the dendritic cell and its role in adaptive immunity. We are proud to say that our book is in line with these discoveries, because 3 chapters cover the problems of innate and adaptive immune response in case of viral hepatitis.

\title{
How to reference
}

In order to correctly reference this scholarly work, feel free to copy and paste the following:

Yukihiro Shimizu (2011). Immunopathogenesis and Immunotherapy for Viral Hepatitis, Viral Hepatitis Selected Issues of Pathogenesis and Diagnostics, Dr. Sergey Mukomolov (Ed.), ISBN: 978-953-307-760-4, InTech, Available from: http://www.intechopen.com/books/viral-hepatitis-selected-issues-of-pathogenesis-anddiagnostics/immunopathogenesis-and-immunotherapy-for-viral-hepatitis

\section{INTECH}

open science | open minds

\section{InTech Europe}

University Campus STeP Ri

Slavka Krautzeka 83/A

51000 Rijeka, Croatia

Phone: +385 (51) 770447

Fax: +385 (51) 686166

www.intechopen.com

\section{InTech China}

Unit 405, Office Block, Hotel Equatorial Shanghai

No.65, Yan An Road (West), Shanghai, 200040, China

中国上海市延安西路65号上海国际贵都大饭店办公楼405单元

Phone: +86-21-62489820

Fax: $+86-21-62489821$ 
(C) 2011 The Author(s). Licensee IntechOpen. This is an open access article distributed under the terms of the Creative Commons Attribution 3.0 License, which permits unrestricted use, distribution, and reproduction in any medium, provided the original work is properly cited. 